\title{
Coronary Artery Disease -Thinking Beyond Atherosclerosis
}

\author{
Kumayl Al-Lawati ${ }^{1}$, Sayqa Arif ${ }^{1}$, Benjamin Rhodes ${ }^{2}$, Jorge G Mascaro' ${ }^{1}$, John N Townend1 and Adrian Warfield ${ }^{3}$ \\ ${ }^{1}$ Department of Cardiology and Cardiothoracic Surgery, University Hospitals Birmingham, United Kingdom
}

${ }^{2}$ Department of Rheumatology, University Hospitals Birmingham, United Kingdom

${ }^{3}$ Department of Pathology, University Hospitals Birmingham, United Kingdom

Submission: March 06, 2018; Published: April 20, 2018

*Corresponding author: John N Townend, Department of Cardiology and Cardiothoracic Surgery, University Hospitals Birmingham, Edgbaston, Birmingham B15 2TH, United Kingdom, Tel: 0044 (1)21 371 4623; Fax: 0044 (1)21 371 4496; Email: john.townend@uhb.nhs.uk

\section{Introduction}

Aortitis involving the coronary arteries is rare [1,2]. Affected individuals may develop myocardial ischaemia due to stenosis of the coronary ostia and/or aortic valve (AV) regurgitation. We report a case of recurrent ostial coronary artery lesions in a young woman.

\section{Case}

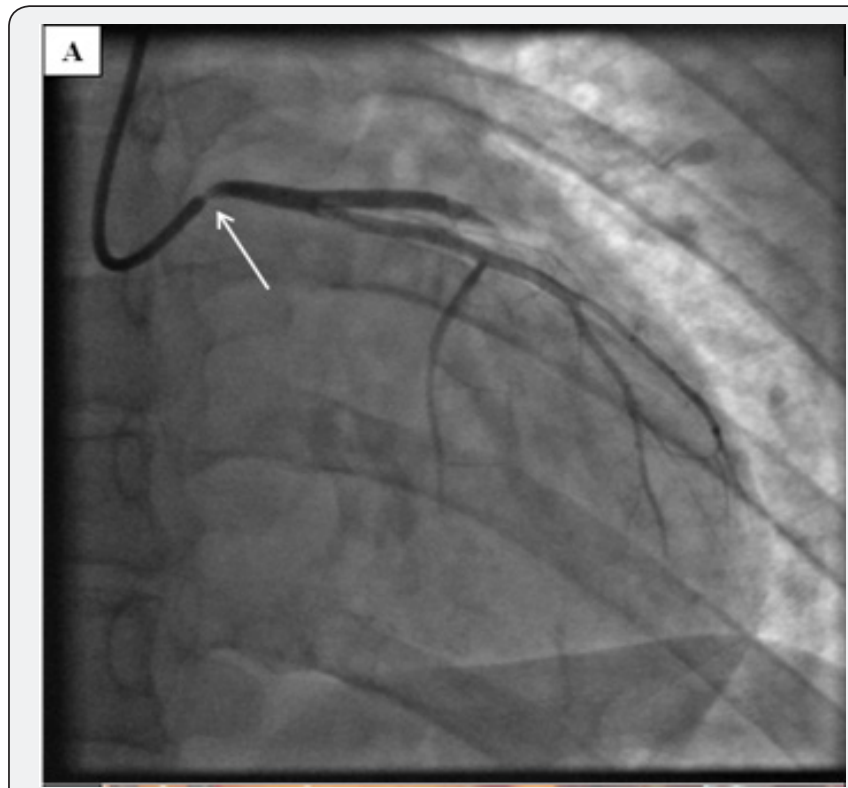

Figure A: Coronary angiogram showing ostial LMS artery stenosis (arrow)

A 27-year-old Caucasian lady was admitted with chest pain at rest suggestive of myocardial ischemia. Clinical examination was normal. The electrocardiogram showed lateral T-wave inversion. High-sensitivity troponin $\mathrm{T}$ level was elevated at 18ng/L ( $99^{\text {th }}$ centile $\left.13 \mathrm{ng} / \mathrm{L}\right)$. The CRP was $32 \mathrm{mg} / \mathrm{L}$ and normalised within 24 hours. Echocardiography showed anterior wall hypokinesia with good left ventricular function and a normal AV. She was treated with aspirin, clopidogrel and enoxaparin. Coronary angiography showed severe ostial left main stem (LMS) artery stenosis (Figure A) but otherwise normal coronary arteries. Magnetic resonance imaging (MRI) showed a structurally normal aorta and branch aortic vessels, with no evidence of inflammation. She had a background of a seronegative inflammatory polyarthritis with uveitis, both of which were quiescent. An autoantibody screen, C3/C4 complements levels, syphilis and virology screen were normal.

Coronary artery intravascular ultrasound (IVUS) confirmed ostial luminal narrowing of the LMS artery due to adventitial constriction rather than atheroma. A drug-eluting stent (DES) was implanted. The initial diagnosis was that of a localised aortitis but steroids were not initiated given her lack of systemic symptoms, normal inflammatory markers and absence of vasculitis elsewhere.

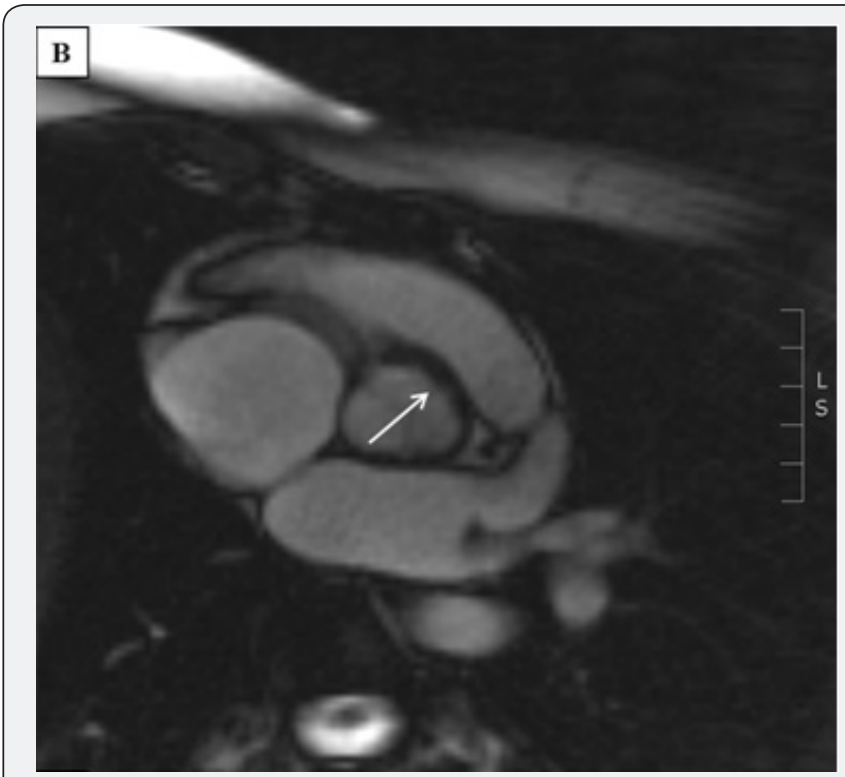

Figure B: Cardiac magnetic resonance imaging of the aorta showing thickened aortic root at level of Sinus of Valsalva (arrow) 


\section{Journal of Cardiology \& Cardiovascular Therapy}
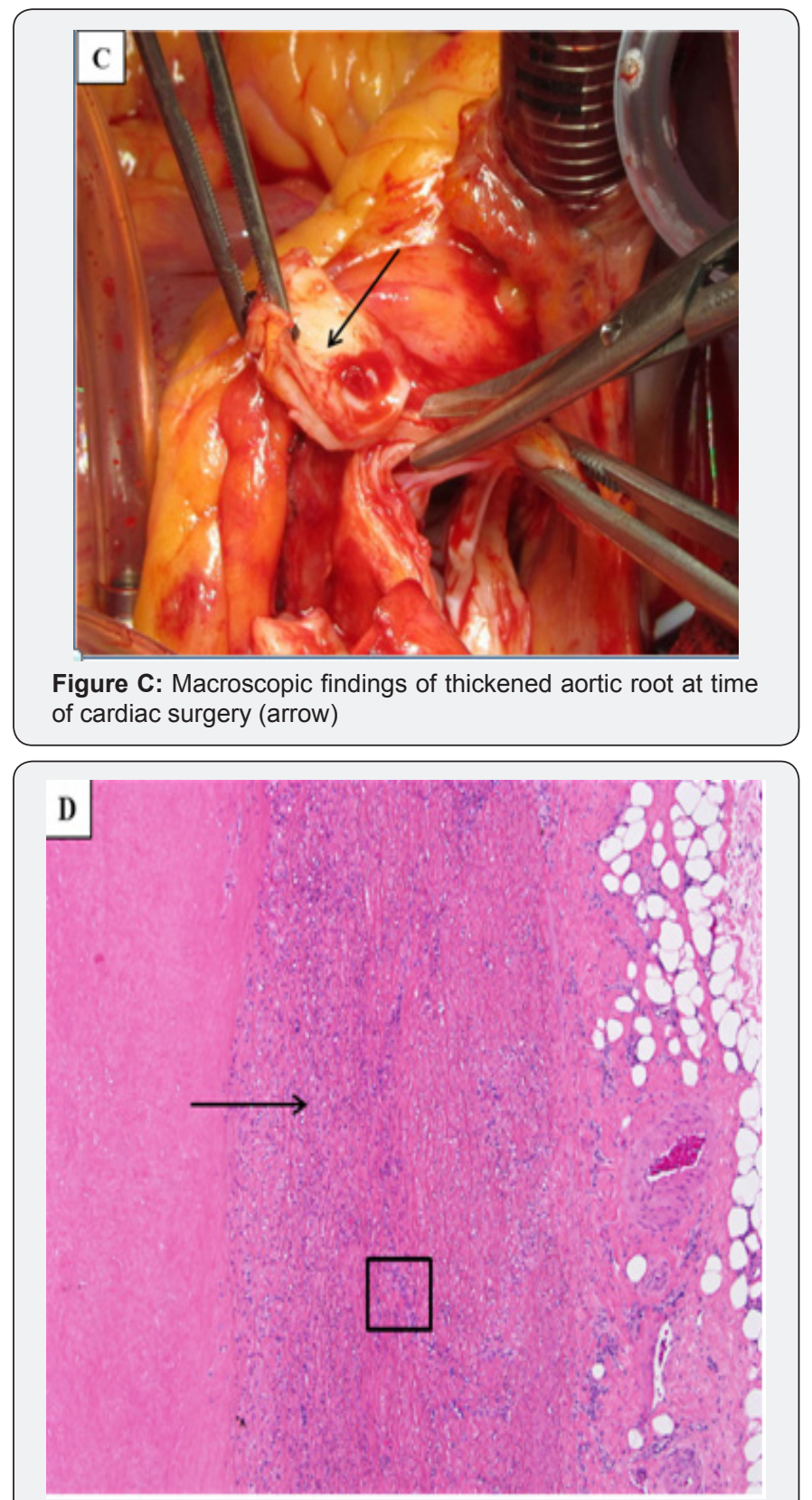

FigureD: Haematoxylin and eosin stain at $4 x$ magnification showing intimal proliferation with lymphocytic infiltration (arrow) multinucleate giant cells (black square).

Over the next 18 months, this lady presented twice with worsening angina. On the first occasion, the LMS artery stent was patent and a new ostial RCA stenosis was seen. IVUS showing adventitial disease and the RCA stenosis was treated with a DES. On the second occasion, there was severe in-stent re-stenosis of both the LMS and RCA stents. Echocardiography demonstrated moderate AV regurgitation with cusp thickening. An MRI showed focal aortitis and a thickened aortic root (Figure B). She underwent coronary artery bypass grafting (CABG) and replacement of the $\mathrm{AV}$ and aortic root. Intra-operatively, the aortic root was thickened with an inflamed adventitia, in keeping with an aortitis (Figure C). Histology showed mixed inflammatory cell influx and multinucleate giant cells (Figure D), consistent with Giant Cell Aortitis with involvement of the AV.

Post-operative Positron-Emission Computed Tomography (PET-CT) showed localised uptake proximal to the aorta-graft anastomosis, but no other vascular involvement. Corticosteroids were commenced (Prednisolone $0.5 \mathrm{mg} / \mathrm{kg}$ ) with Methotrexate. Six months later, the steroids have been discontinued and she remains well and symptom-free on methotrexate.

\section{Discussion}

While isolated ostial coronary artery stenoses are rare and can be due to atherosclerosis, other causes should be considered. These include aortic wall disease due to previous radiotherapy, syphilis and inflammatory aortitis (idiopathic giant cell, Takayasu's arteritis, rheumatoid arthritis and ankylosing spondylitis). Typically inflammatory aortitis patients are older ( $>55$ years) and present with easily recognisable aortic involvement - aneurysms, stenosis, dissection or AV regurgitation [3].

Unusually, this lady presented with isolated coronary artery stenosis, without initial aortic involvement. Her histology was consistent with Giant Cell Aortitis, which is an idiopathic proximal aortitis. PET-CT failed to show widespread vascular involvement and her inflammatory markers were near normal on initial and subsequent presentations, going against an active inflammatory process.

Definitive management includes coronary revascularisation and replacement of diseased aortic tissue. Stenting may not be the correct strategy because active aortitis may lead to restenosis. CABG should use internal mammary arteries when possible for longevity and to avoid the insertion of vein grafts in to possibly inflamed aortic tissue. Evidence to support the use of immunosuppressive drugs in this condition is sparse. They are often used pragmatically to limit the risk of post-surgical recurrence. Their long-term benefit is uncertain $[4,5]$.

\section{Learning Points for Clinicians}

This case highlights the importance of considering an alternative cause, such as an inflammatory aortitis, for ostial coronary disease in a young patient with few cardiovascular risk factors. In cases of left main stem disease due to aortitis, prompt coronary revascularisation is required and consider immunosuppressive.

\section{References}

1. Hountis P, Dedeilias P, Vourlakou C, Bolos K (2010) Isolated bilateral coronary artery ostial stenosis in aortitis syndrome. Hellenic J Cardiol 51(5): 472-474.

2. Rigatelli G, Zuin M, Picariello C, Cardaioli P, Roncon L (2016) Aortitisrelated isolated bilateral coronary artery stenosis in a young woman with acute coronary syndrome. Int J Cardiol 223: 111-112.

3. Rojo-Leyva F, Ratliff N, Cosgrove D, Hoffman G (200) Study of 52 patients with idiopathic aortitis from a cohort of 1204 surgical cases. Arthritis Rheum 43(4): 901-907. 
4. Topel I, Zorger N, Steinbauer M (2016) Inflammatory diseases of the aorta: Part 1: Non-infectious aortitis. Gefasschirurgie 21(Suppl 2): 8086. CC Commons Attribution 4.0 License
Cols $10.19080 /$ JOCCT.2018.10.555783
5. Townend JN, Emerry P, Davies MK, Littler WA (1991) Acute aortitis and aortic incompetence due to systemic rheumatological disorders. Int J Cardiol 33(2): 253-258.

Your next submission with Juniper Publishers will reach you the below assets

- Quality Editorial service

- Swift Peer Review

- Reprints availability

- E-prints Service

- Manuscript Podcast for convenient understanding

- Global attainment for your research

- Manuscript accessibility in different formats

( Pdf, E-pub, Full Text, Audio)

- Unceasing customer service

Track the below URL for one-step submission https://juniperpublishers.com/online-submission.php 